\title{
Kebangkitan Politik Identitas dalam Proses Demokratisasi di Indonesia Pasca Orde Baru
}

Mahpudin ${ }^{1}$

mahpudinapud3@gmail.com

${ }^{1}$ Departemen Politik Pemerintahan, Universitas Gadjah Mada, Yogyakarta

DOI: $10.22219 /$ sospol.v7i2.10781

\begin{abstract}
This paper attempts to explain how the rise of identity politics in Indonesia after the New Order. In order to answer this question, this paper uses the theory of identity politics that was initiated by several experts. The research method uses qualitative-descriptive, while data collection is done through literature review. The results of the study conclude that the rise of identity politics in Indonesia after Suharto caused the journey of democracy in Indonesia for two decades to not progress towards substantial democracy. In the end, Indonesian democracy is still trapped in procedural democracy, which is only intertwined with election matters and the process of elite turnover. However, in practice the life of citizens still does not show a democratic life. Various cases of violence and intolerance as well as the strengthening of identity sentiments on the basis of ethnicity and religion have led to the practice of discrimination and exclusion of other different identity groups. This condition is often exploited by political elites who play an important role in sharpening identity and religious sentiments to gain power, especially entering the election period.
\end{abstract}

\begin{abstract}
Abstrak
Tulisan ini berupaya menjelaskan bagaimana kebangkitan politik identitas di Indonesia pasca Orde Baru. Guna menjawab pertanyaan tersebut, tulisan ini menggunakan teori tentang politik identitas dan metode penelitian kualitatifdeskriptif, dengan pengumpulan data dilakukan melalui kajian literatur. Hasil kajian menyimpulkan bahwa kebangkitan politik identitas di Indonesia pasca Soeharto menyebabkan pejalanan demokrasi di Indonesia selama dua dekade tidak berjalan maju ke arah demokrasi substansial. Demokrasi Indonesia pada akhirnya masih terjebak pada demokrasi prosedural yang hanya berkelindan soal urusan pemilu dan proses pergantian elit. Namun dalam praktik kehidupan warga negara masih belum menunjukkan kehidupan yang demokratis. Berbagai kasus kekerasan dan intoleransi serta menguatnya sentimen identitas atas dasar etinisitas dan agama telah menimbulkan praktik diskriminasi dan pengeksklusian terhadap kelompok identitas lain yang berbeda. Kondisi ini sering kali dimanfaatkan oleh elit politik yang memainkan peran penting dalam mempertajam sentimen identitas dan agama untuk mendapatkan kekuasaan, terutama memasuki masa pemilu.
\end{abstract}

\author{
Keywords \\ Demokrasi, Indonesia, Pemiliban \\ Umum, Politik Identitas

\section{Article History} \\ Received January 3, 2020 \\ Revised August 5, 2021 \\ Accepted November 11, 2021 \\ Published November 16, 2021

\section{Corresponding Author Mahpudin. Departemen Politik Pemerintahan, Universitas Gadjah Mada, Jl. Sosio Yusticia, Bulaksumur, Yogyakarta. 55281.}

\section{Pendahuluan}

Pasca tumbangnya rezim otoritarian Orde Baru, Indonesia memasuki masa transisi ke arah sistem politik yang lebih terbuka dan demokratis. Hal ini ditandai dengan dibukanya keran kebebasan politik yang diikuti dengan fenomena menjamurnya partai politik baru, kebangkitan asosiasi masyarakat sipil dan kebebasan media. Selain itu, format institusi dan kelembagaan politik yang baru mulai deperkenalkan lewat sejumlah aturan pemilu yang lebih demokratis dan 
perimbangan kekuasaan antar lembaga negara yang dikenal sebagai trias politica. Satu hal yang tidak kalah penting adalah format perimbangan kekuasaan dari sentralisasi bergeser ke desentralisasi melalui pintu otonomi daerah.

Jika melihat berbagai perubahan format dan setting politik ini, nampaknya ada optimisme terkait masa depan Indonesia yang lebih demokratis, sejahtera dan berkeadilan. Namun banyak pengamat menilai bahwa demokrasi yang diperkenalkan pasca Orde Baru terjebak pada aspek prosedural sehingga tidak banyak mengubah kehidupan sosial politik yang lebih substantif. Hal ini ditandai dengan meskipun terjadi perubahan infrastruktur kelembagaan politik dan perimbangan kekuasaan yang lebih demokratis, tetapi ide representasi masih lemah karena dimonopoli oleh aktor dominan semantara kekuatan sipil society tidak menunjukkan kekuatan yang berarti sebagai penyeimbang dominasi kekuasaan negara dan elit politik. Bahkan banyak aktivis dari kalangan masyarakat sipil berhasil masuk ke lembaga politik karena mempolitisasi masyarakat sipil (Tornquist, 2013). Selain itu, demokrasi di Indonesia pasca Orde Baru hanya dikuasi oleh segelintir elit oligarkis yang berusaha mengakumulasi kekayaan dengan berhubungan atau terjun langsung dalam dunia politik baik melalui jalur pendirian partai politik maupun lewat pintu pemilu (Hadiz dan Robinson, 2004; Winters, 2014). Semantara partai politik yang tumbuh dan berkembang pasca Soeharto menjadi lebih pragmatis dengan membangun sistem kepartaian yang terkartelisasi untuk menghisap sumber daya politik ekonomi (Slater, 2004; Mietzner, 2008; Ambardi, 2009). Patologi dan paradoks yang ditemukan dalam perjalanan demokrasi pasca Orde Baru oleh banyak ahli politik ini mengantarkan pada sebuah kesimpulan bahwa demokrasi di Indonesia mengalami kemandegan jika tidak dikatakan kemunduruan.

Namun, assesment demokrasi oleh para ahli cenderung melihat hanya dari perspektif elit dengan pendekatan struktural. Penilaian demokrasi dari perspektif society belum banyak muncul. Padahal society sebagai bagian dari entitas demokrasi menjadi penting untuk diamati. Maju dan mundurnya demokrasi dapat dilihat dari sejauh mana society dan relasi politik yang bekerja didalamnya dapat mendukung atau justru menghambat bekerjanya demokrasi. Saya berargumen bahwa gelombang demokratisasi yang diperkenalkan pasca Orde Baru menjadi pintu bagi kebangkitan politik identitas yang pada akhirnya menciderai makna demokrasi itu sendiri. Rakyat menjadi kian mudah terfragmentasi oleh sekat-sekat identitas. Keadaan ini semakin diperparah oleh elit politik yang mencoba mencari kekuasaan dengan mengeksploitasi politik identitas, utamanya menjelang kontestasi elektoral.

Politik identitas sebagai konsekuensi dari dibukannya keran demokrasi sejak tahun 1998 menjadi menarik untuk dikaji lebih mendalam mengingat isu-isu identitas sampai hari ini masih menghiasi wajah perpolitikan indonesia baik di tingkat nasional maupun lokal. Proses kandidasi dalam politik elektoral, perilaku pemilih dalam menentukan calon pemimpin, tuntutan akan pemekaran daerah, dan meletusnya berbagai konflik komunal tidak lepas dari politik identitas (Nordholt \& Klinken, 2007). Di tingkat nasional, proses politik pemilihan calon presiden periode 2019-2024 yang mengkontestasikan dua pasangan Jokowi-Ma'ruf Amin dan Prabowo-Sandiaga Uno. Sementara, di tingkat lokal, politik elektoral pada Pemilihan Kepala Daerah (Pilkada) DKI Jakarta tahun 2017 adalah dua fenomena kontemporer yang tidak bisa dilepaskan dari analisa tentang politik identitas. Berangkat dari paparan diatas, tulisan ini hendak menjelaskan bagaimana politik identitas digunakan dalam perpolitikan di Indonesia pasca Orde Baru. 
Berbagai riset terdahulu banyak yang telah membahas mengenai politik Identitas. Sebagaimana riset dari Agnes Heller (dalam Abdillah, 2002:16) yang menyimpulkan politik identitas sebagai gerakan politik yang menempatkan perbedaan sebagai kategori politk utama (politics of difference). Proses pencarian perbedaan ini berimplikasi pada praktik meniadakan orang lain (lian) yang tidak termasuk dalam kategori identitas yang sama. Konsekuensinya, politik identitas membentuk demarkasi yang sangat tegas antara siapa kelompok yang terlibat dalam identitas yang sama dan kelompok lain yang berbeda dengan membentuk kategori "kami" (we) dan "mereka (they)", dalam (in) dan luar (out) (Morowitz, 1998). Berangkat dari definisi ini, politik identitas dilihat dari sudut pandang politik perbedaan. Individu atau komunitas dalam suatu masyarakat akan mencari kesamaan-kesamaan identitas sebagai pengikat indivu ke dalam kelompok. Sementara, ketika terdapat perbedaan identitas, maka secara langung orang atau kelompok yang berbeda ini tidak masuk kategori kelompok identitas yang lain. Kendati demikian, garis pisah antar kelompok yang berbeda ini tidak selalu tegas. Pada konteks tertentu, dalam sebuah kelompok masyarakat terdapat tumpah tindih dan garis pemisah yang kabur dalam membedakan kelompok identitas lainnya. Khususnya bagi invidu atau kelompok yang memiliki lebih dari satu identitas. Karena itu, identitas adalah hasil konstruksi terus-menerus dan tidak pernah final (fixed). Makna identitas terus dikontestasikan untuk mencapai posisi subjek tertentu yang membedakan dengan kelompok yang lain.

Sementara itu, Fukuyama (2018) dalam bukunya "Identity: The Demand for Dignity and the Politics of Resentment" dengan detail memotret bagaimana politik identitas terjadi bahkan di negara maju sekalipun seperti Amerika Serikat dan negara-negara di eropa lain. Demokrasi liberal yang memberikan kebebasan kepada setiap orang menyebabkan identitas menjadi diskursus yang terus diperjuangkan karena setiap orang merasa bahwa keberadaan identitasnya harus diakui dan dihormati di tengah masyarakat. Implikasinya, identitas yang muncul sering kali saling bertentangan satu sama lain dengan identitas lainnya menyebabkan konflik di masyarakat. Menurut Fukuyama, disamping perjuangan mendapat pengakuan sosial, tuntutan tersebut kerap kali berubah ingin menjadikan kelompok yang bersangkutan lebih superior dibandingkan dengan kelompok lain. Setiap kelompok merasa memiliki hak untuk diperlakukan lebih tinggi sehingga mengeksklusi dan memarginalkan kelompok lain. Tuntutan akan superioritas identitas kelompok ini membuat mereka menjadi anti kritik dan memandang bahwa identitas yang lain rebih rendah. Akibatnya, ujaran kebencan menjadi lahan yang subur. Hal ini sering kali dimanfaatkan oleh elit politik untuk mendapatkan dukungan massa. Maka tidak heran jika politik di Amerika Serikat penuh dengan adu domba dan ujaran kebencian setiap kali menjelang tahun-tahun politik. Donald Trump adalah contoh terbaik yang mengkonfirmasi tesis Fukuyama bahwa kemenangannya sebagai presiden tidak lepas dari strategi politik yang memainkan sentimen identitas. Hal tersebut mempertegas bahwa demokrasi liberal tengah menghadapi ancaman (Levistky \& Ziblatt: 2018).

Berdasarkan paparan diatas, secara umum dapat dipahami bahwa politik identitas merupakan sebuah fenomena politk yang terjadi pada masyakat dibelahan dunia mana pun baik di negara maju maupun berkembang dengan ragam pola dan karakteristik sesuai dengan konteks yang terjadi di negara tersebut. Politik identitas perlu dibedakan dengan identitas politik. Istilah identitas politik mengacu pada konstruksi yang menentukan kepentingan posisi subjek dalam suatu masyarakat yang membedakan dengan identitas masyarakat lain. Sementara politik identitas 
dapat dipahami sebagai bentuk pemanfaatan identitas sebagai sarana dan sumber politik (Haboddin, 2012:119). Identitas yang dimaksud berupa kesamaan tehadap etnis, agama, ras, jenis kelamin, kepercayaan, adat, kelompok dan golongan. Dalam kajian ilmu politik, istilah politik identitas mulai muncul ke permukaan dari hasil pertemuan Internasional Asosiasi Ilmuan Politik Internasional pada tahun 1994 yang menghasilkan kesepakatan bahwa politik identitas masuk dalam kajian ilmu politik (Abdillah, 2002:16). Kendati demikian, pemaknaan politik identitas bersifat cair sebab para ahli berbeda pendapat dalam mendefinisikan istilah politik identitas.

Politik identitas tidak hanya soal pencarian perbedaan identitas. Politik identitas dapat muncul sebagai bentuk perjuangan politik dalam merebut kekuasaan berdasarkan identitas tertentu. Perjuangan merebut kekuasaan politik ini dilakukan oleh kelompok yang selama ini mengalami marginalisasi, penindasan, dan keterpinggiran secara sosial, politik, ekonomi dan budaya dalam kurun waktu yang realtif cukup lama (Kristanus dalam Buchari, 2014:27). Sehingga politik identitas utamanya bukan karena dipicu oleh pengorganisiran kelompok lewat afiliasi organisasi atau partai tentutu, melainkan terlebih dahulu dipicu karena perasaan terisolasi dan ketidakadilan (Buchari, 2014:28). Pratik marginalisasi dan diskriminasi ini dapat dilakukan oleh kelompok lain dalam praktik relasi sosial atau oleh rezim yang berkuasa. Oleh sebab itu, politik identitas pada umumnya sebagai perjuangan politik dalam menuntut pengakuan (politics of recognition) dan kesetaraan (politics of equal respect).

Pandangan lain berargumen bahwa politik identitas sebagai bentuk strategi dan retorika yang biasa digunakan oleh para elit politik untuk melanggengkan jalan merebut kekuasaan (Chandrakirana, 1989). Elit politik atau para pemimpin kelompok dengan sengaja mengkonstruksi identitas untuk mendapatkan dukungan dan legitimasi masyarakat dari kelompok identitas tetentu untuk memenangkan persaingan. Akibatnya, dalam sebuah fenomena politik yang memperebutkan akses terhadap jabatan dan sumber daya, terdapat kontestasi identitas dalam sebuah masyarakat. Sistem demokrasi yang membuka peluang kepada siapa pun secara bebas untuk bersaing dalam berebut kekuasaan, membuat proses persaingan penuh dengan ketidakpastian. Implikasinya, elit politik dan pemimpin kelompok mengeksploitasi simbol-simbol identitas untuk memobilisasi masyarakat sehingga politisiasi sipil tidak dapat dihindari karena mobilisasi sipil menggunakan sentimen identitas sangat efektif karana melibatkan ikatan emosional kelompok (Jumadi, 2003).

Politik identitas sebagai strategi dan gerakan politik untuk merebut kekuasaan dalam perjalanannya mengalami pergeseran. Beyme (dalam Abdillah, 200:17) menganalisis karakter gerakan politik identitas melalui tiga tahap. Petama, tahap pramodern. Konflik dan perpecahan kelompok kesukuan dan kebangsaan menghasilkan gerakan politik identitas yang dimobilisasi oleh pemimpin kelompok dengan tujuan merebut kekuasaan dari satu penguasa ke penguasa yang baru. Kedua, tahap modern. Gerakan politik identitas muncul secara kondisinoal dimana perpecahan kelompok dan kebangsaan memerlukan sumber-sumber untuk dimobilisasi. Implikasinya, terjadi pola interaksi dua arah, yaitu mobilisasi dari atas oleh pemimpin dan partisipasi dari bawah oleh anggota kelompok identitas. Peran pemimpin tidak lagi dominan sehingga mengharuskan adanya pembagian kekuasaan. Ketiga, tahap post modern. Gerakan politik identitas muncul secara acak mengikuti dinamikanya sendiri. Bentuk protes atas nama identitas tertentu base on kesadaran diri yang menuntut otomoni sebagai tujuan akhir. 
Dari pemaparan ini, maka dapat dilihat bahwa para ahli memaknai fenomena politik identitas secara berbeda. Setidaknya, jika merujuk pada pemaparan diatas terdapat tiga narasi yang dapat menjelaskan politik identitas. Pertama, politik identitas memfokuskan perbedaan sebagai ketegori politik. Kedua, politik idenitas sebagai ekspresi hadirnya perasaan marginalisasi dan ketidakadilan dalam kehidupan politik, sosial, ekonomi dan budaya dalam waktu yang cukup lama. Ketiga, politik identitas sebagai strategi politik para elit untuk memperoleh kekuasaan. Apabila melihat varian pemaknaan politik identitas ini, implikasinya politik identitas dapat dilihat sebagai dua sisi mata uang. Di satu sisi, praktik politik identitas dapat berdampak positif karena dapat memperkuat ikatan komunitas dan mampu merubah karakter politik yang eksklusif dan menindas menjadi inklusif melalui sejumlah agenda perjuangan politik. Namun di sisi lain, politik identitas dapat berdampak negatif. Proses pencarian identitas dengan mengkonstruksi perbedaan berpotensi menimbulkan konflik dan kekerasan komunal baik secara horizontal maupun vertikal. Suatu kelompok yang eksis dalam sebuah masyarakat akan saling meniadakan satu sama lain untuk mendapatkan tujuan tertentu.

Dua implikasi tersebut menempatkan politik identitas sebagai sebuah kajian yang akan terus mendapat perhatian terutama yang berkaitan dengan identitas keetnisan, gender, masyarakat pribumi dan masyarakat lokal (Geertz, 1963). Realitas masyarakat yang beragam identitas ini menyebabkan konflik sulit dihindari terlebih bagi negara-negara dengan karakteristik yang plural termasuk Indonesia. Sebab merujuk pada tesis Furnival (dalam Lee, 2009) menyebut bahwa masyarakat plural sebagai masyarakat yang teridiri dari lebih dari satu identitas kelompok dimana mereka hidup berdampingan tetapi tidak berbaur sehingga sangat berpotensi terjadinya gesekan antar kelompok karena diantara kelompok-kelompok dengan identitas yang berbeda ini tidak ada kehendak hidup bersama (common will) untuk menyatu dalam satu identitas yang lebih besar..

\section{Metode}

Penelitian ini menggunakan jenis penelitian kualitatif-deskriptif terkait perjalanan demokrasi di Indonesia pasca Orde Baru dengan menggunakan perspektif society. Creswell (2014) dalam menjelaskan bahwa desain penelitian kualitatif adalah proses riset dan pemahaman metodologi yang meneliti fenomena sosial dalam segala permasalahan manusia. Penelitian ini menggunakan data sekunder melalui studi literatur dari buku, jurnal, dan media online, serta bahan rujukan lainnya yang relevan dalam penelitian ini.

\section{Hasil dan Pembahasan}

\section{Potret Politik Identitas Pada Masa Kolonial Hingga Rezim Orde Baru}

Politik identitas pada masa kolonial hingga rezim Orde Baru mengalami pasang surut. Hal ini tidak lepas sebagai akibat dari pergantian rezim dan setting politik yang terjadi pada saat itu. Rezim kolonial yang sangat sentralistik dan otoriter sangat mengubur terjadinya sentimen identitas yang dapat berujung pada konflik dan kekerasaan komunal sehingga dapat merugikan kepentingan penjajah. Pada masa pendudukan Belanda, terdapat klasterisasi masyarakat berdasarkan ekonomi dan sosial. Klaster pertama ditempati oleh bangsa eropa yang tidak lain adalah bangsa penjajah. Mereka berperan sebaga penguasa utama yang mengendalikan pusat pemerintahan. Klaster kedua ditempati oleh etnis China (Tionghoa) yang menjalankan fungsi perdagangan. Sementara klaster terbawah ditempati oleh masyarakat pribumi. Ketiga klaster ini 
hidup berdampingan menempati suatu wilayah tetapi tidak salah berbaur. Mereka hidup masingmasing tanpa mengasilkan satu kesatuan bersama.

Sejarah kerusuhan etnis pertama terjadi di Batavia (saat ini Jakarta). Terjadi pembantaian etnis China oleh Belanda pada tahun 1740. Peristiwa berdarah terjadi karena pemerintah Belanda merasa tidak nyaman dengan keberadaan komunitas China yang masuk ke Batavia untuk berdagang. Selain itu, Belanda curiga bahwa pengusaha-pengusaha China berada di pihak masyarakat Indonesia untuk melawan penjajahan Belanda. Kecurigaan tersebut menguat dengan melihat banyaknya etnis China yang mulai berani melawan penjajah. Sementara, etnis China sudah menaruh kebencian kepada Belanda yang mengeluarkan berbagai kebijakan yang menghambat aktivitas perekonomian etnis China. Implikasinya, terjadi kerusuhan berdarah selama 13 hari dimulai pada 9 Oktober 1740 yang menyebabkan tidak kurang dari 10.000 ribu warga China meninggal. Peristiwa ini dikenal dengan sebutan Geger Pecinan (Tirto.id, 2017).

Pada umumnya pemerintah kolonial sangat menghindari terjadinya konflik identitas. Fakta bahwa masyarakat yang majemuk ini rawan terjadi bentrokan yang berujung tindakan anarki. Karena itu, rezim kolonial berusaha untuk mengintegrasikan kelompok yang berbeda ini dengan mendoktrin isu nasionalisme. Akibatnya, masyarakat Indoensia saat itu mengalami pergeseran dari populasi rasial berdasarkan identitas tertentu ke populasi nasional. Selain itu, masyarakat yang majemuk ini membuat rezim kolonial menggunakan cara-cara otoriter dan sentralistik. Tindakan tersebut menyebabkan nilai-nilai lokalitas mengalami pengikisan. Tindakan represivitas rezim kolonial pada akhirnya mampu meredam munculnya konflik berdasarkan politik identitas (Furnival, dalam Lee, 2009).

Isu tentang politik identitas terus mengalami keterpinggiran hingga masa awal kemerdekaan sampai rezim orde lama, Soekarno. Walaupun isu identitas pada dasarnya menjadi kajian para pengamat tahun 1950-an, tetapi isu yang paling dominan lebih banyak memfokuskan pada kajian tentang partai politik, politik aliran dan nation-building (Nordholt \& Klinken, 2009). Politik aliran menjadi penting untuk dilihat karena munculnya politik aliran sebenarnya ditopang oleh politik identitas. Politik aliran dipopulerkan oleh Clifort Geertz (1983) yang melihat masyarakat Jawa terbagi kedalam tiga varian yaitu abangan, santri dan priyayi. Perbedaan identitas masyarakat Jawa ini menyebabkan konflik komunal berdasarkan sentimen kepercayaan atau agama. Konflik terjadi karena adanya benturan ideologis dan ketidaksenangan dengan kelompok lain, pengaruh sistem stratifikasi sosial dan perjuangan kekuasaan politik yang cenderung mempertajam perbedaan agama dan kepentingan politik (Geertz, 1983).

Politik aliran yang dibangun atas perbedaan identitas ini berpengaruh terhadap preferensi politik masyarakat dalam memilih partai politik era 1950-an. Kelompok islam cenderung memilih partai-partai dengan platform islam seperti NU dan Masyumi. Sementara kelompok abangan dengan tradisi kebudayaan Jawa yang sangat kental cenderung dekat dengan PNI atau PKI (Feith dalam Mietzner, 2008). Partai-partai pada masa ini berhasil membangun kedekatan dengan konstituen mereka tidak lepas karena strategi mereka menggunakan sentimen identitas yang terus dikontruksi sehingga menjadi sebuah ideologi politik bagi masyarakat dalam menentukan preferensi politik. Era orde lama ditandai dengan munculnya ketegangan yang bersifat horizontal (Geertz, 1983).

Namun memasuki Orde Baru yang ditandai oleh kehadiran rezim otoritarian Soeharto, ketegangan komunal berdasarkan identitas tidak banyak muncul ke permukaan. Orde Baru 
berhasil mengubur sentimen berbau identitas melalui represivitas rezim menggunakan militer (Nordholt \& Klinken, 2009). Transisi dari rezim orde lama ke Orde Baru ditandai dengan pergeseran ketegangan (konflik) dari bersifat horizontal ke vertikal. Ketegangan politik aliran berdasarkan sentimen agama luntur, meski tidak sepenuhnya pada masa rezim Soeharto. Hal ini di latar belakangi oleh beberapa faktor: pemberangusan PKI, diperkenalkannya kebijakan masa mengambang (depolitisasi massa), kebijakan asas tunggal (pancasila) dan hadirnya dominasi Golkar (Geertz, 1983).

\section{Penggunaan Politik Identitas dalam Proses Demokratisasi Pasca Orde Baru}

Runtuhnya Orde Baru Soeharto pada tahun 1998 telah membawa politik Indonesia menuju angin segar perubahan ke arah yang lebih terbuka dan liberal. Rezim otoritarianisme digantikan dengan rezim demokratis yang ditandai dengan dibukanya keran kebebasan sipil dalam politik, reformasi kelembagaan, dan diperkenalnya konsep desentralisasi melalui pintu otonomi daerah. Kekuasaan yang semula tersentralisasi di pemerintah pusat, pasca Orde Baru, kekuasaan tersebar ke berbagai daerah dengan beragam aktor politik. Baik aktor lama maupun aktor baru saling berkontestasi memperebutkan kekuasaan dan sumber daya ekonomi politik melalui peluang yang ditawarkan dalam setting demokrasi liberal (Haryanto, 2009).

Tumbangnya rezim Orde Baru juga diikuti oleh lemahnya kontrol negara, dimana hal itu berimplikasi pada perebutan kekuasaan antara elit politik dan masyarakat sipil. Pada gilirannya, politik perebutan kekuasaan antar para aktor yang terlibat didalamnya menjadi sangat kental dengan unsur politik Identitas. Pergulatan dalam mencari identitas etnis dan keagamaan sebagai instrumen dalam perebutan kekuasaan menjadi ciri khas lanskap politik Indonesia pasca Orde Baru. Hal ini tampak dari banyaknya peristiwa kerusuhan dan konflik atas dasar identitas etnis dan agama yang terjadi di Indonesia sejak runtuhnya Orde Baru. Tercatat, pada kisaran tahun 1997 hingga 2002 terjadi konflik antar masyarakat di Maluku, Kalimantan Barat dan Tengah, dan Sulawesi Tengah. Selain itu, pada periode yang juga sering disebut sebagai periode transisi pasca Orde Baru, terdapat berbagai tuntutan untuk pemerkaran daerah yang dilandasi oleh sentimen sentimen etnis dan agama. Sebagai contoh, pada tahun 1999, terdapat 300 kabupaten di Indonesia, dimana jumlah tersebut meningkat pesat menjadi 440 pada tahun 2004 (Nordholt \& Klinken, 2009). Konflik dan kekerasan komunal serta tuntutan pemekaran daerah pada masa transisi menggambarkan bagaimana repetoar etnis dan agama digunakan untuk mengekspresikan ambisi politik dan memobilisasi dukungan rakyat.

Sekalipun masa transisi pasca Orde Baru telah berakhir, politik identitas terus digunakan sebagai perjuangan politik meraih kekuasaan. Sejak tahun 2005, diperkenalnya desain pemilu secara langsung yang memberikan hak politik kepada waga negara untuk memilih calon pemimpin politik, semakin mempertajam eksploitasi politik identitas. Pemimpin politik di daerah selama masa Orde Baru telah ditentukan oleh pemerintah pusat sehingga menutup kesempatan masyarakat lokal memiliki calon pemimpin yang lahir dari putra asli daerah. Namun setelah reformasi dan pemilu langsung, tuntutan untuk memiliki calon pemimpin pribumi menjadi sangat kuat. Implikasinya, politik elektoral sangat kental dengan nuansa politik pribumi dan non primbumi yang dibalut dengan sentimen identitas. Pada satu sisi, kondisi ini memberi peluang politik kepada masyarakat lokal yang selama rezim Orde Baru mengalami marginalisasi dan peminggiran dalam arena politik untuk tampil ke ruang publik merebuat kekuasaan dan sumber 
daya ekonomi politik. Akan tetapi di sisi yang lain, penggunaan politik identitas dalam politik elektoral menyebabkan praktik pengeksklusian dan diskriminasi terhadap warga negara lain yang memiliki identitas berbeda di suatu wilayah.

Setidaknya terdapat beberapa contoh kasus mengenai penggunaan politik identitas dalam proses electoral. Salah satunya terdapat pada pemilihan Gubernur dalam Pilkada tahun 2007 di Kalimantan Barat yang sukses memenangkan Conelis sebagai gubernur yang berasal dari etnis terbesar di Kalimantan Barat, etnis Dayak. Selama ini, sebelum diperkenalkannya desentralisasi dan pemilihan kepala daerah langsung, tidak ada jabatan guburnur dan wakil gubernur di Kalimantan Barat yang berasal dari etnis Dayak. Selain itu, pos-pos pemerintahan lainnya didomominasi oleh birokrat non Dayak. Marjinalisasi dan diskriminasi yang dialami oleh etnis Dayak dalam kurun waktu yang lama hingga masa Orde Baru Soeharto telah membuat ikatan emosional yang sangat kuat yang berakhir pada munculnya politik identitas. Hal ini ditandai dengan kuatnya konsolidasi etnis dayak dalam memilih calon pemimpin yang berasal dari etnis Dayak sebagai gubernur pada Pilkada tahun 2007 dengan memanfaatkan peluang demokrasi dan desentralisasi melaui pintu politik elektoral. Keberhasilan Cornelis menjadi gubernur yang berasal dari etnis Dayak menjadi simbol berhasilnya penggunaan politik identitas dalam merebut kekuasaan. Segera setelah Cornelis terpilih, pos-pos jabatan birokrasi pemerintahan di Kalimantan Barat mulai ditempati oleh birokrat yang berasal dari etnis Dayak (Buchari, 2014). Contoh ini menjelaskan bahwa politik identitas yang memanfaatan peluang demokrasi memberi kesempatan kepada warga negara untuk lepas dan bangkit dari pengalaman marjinalisasi dan diskriminasi dalam kurun waktu yang cukup lama.

Sementara pada kasus pemilihan gubernur DKI Jakarta pada tahun 2017 memberi penjalasan yang berbeda, dimana politik identitas berakhir pada praktik pengeksklusian, diskriminasi terhadap kelompok lain, intoleransi dan konflik berdasarkan identitas agama (Hamid, 2019; Ubaid \& Habibisuband, 2017). Pilkada DKI Jakarta tahun 2017 pada putaran kedua diikuti oleh dua pasangan calon yaitu: Pasangan Ahok-Djarot dan Anis BaswedanSandiaga Uno. Pasangan Anis Baswedan-Sandiaga Uno menggunakan isu identitas berdasarkan etnis dan agama untuk mengalahkan Ahok sebagai calon petahana. Sebagaimana diketahui, Ahok merupakan calon yang berasal dari etnis Tionghoa dan beragama non-muslim. Di tengah perhelatan pesta demokrasi, terjadi mobilisasi massa yang dikenal dengan Aksi Bela Islam untuk mengajak kepada pemilih Jakarta khususnya pemilih muslim untuk tidak memilih Ahok karena bukan seorang muslim. Sebaliknya, aksi ini mengarahkan pemilih untuk memilih Anis-Sandi. Berbagai kampanye negatif berbau politik identitas terus dijalankan oleh tim pemenangan AnisSandi, misalnya mengeluarkan seruan untuk melarang menshalatkan jenazah umat muslim yang memulih Ahok.

Kampanye politik Anis-Sandi menggunakan sentimen agama mendapatkan jalan yang mulus karena pasangan tersebut diusung oleh partai berbasis islam, PKS dan berhasil mendapat dukungan dari organisasi islam, FPI dan para ulama. Begitu massifnya penggunakan politik identitas berbasis agama menyebabkan kekalahan Ahok dalam panggung kontestasi elektoral. Padahal, hasil jajak pendapat yang dilakukan oleh banyak lembaga survei menyebut bahwa tingkat kepuasan masyarakat Jakarta terhadap kepemimpinan Ahok selama menjabat sebagai gubernur Jakarta sampai pada hari menjelang pemilihan selalu berada pada kisaran angka 70 persen. Jika pemilih Jakarta masuk pada kategori pemilih rasional, seharusnya Ahok dipastikan menang. 
Namun kekalahan Ahok justru memperlihatkan pembacaan lain bahwa pemilih di Jakarta masih mudah terjebak pada pertimbangan emosional yang berlandaskan pada kesamaan faktor sosiologis, dalam hal ini agama. Politik identitas menjadi senjata yang sangat ampuh bagi AnisSandi untuk mengalahkan Ahok. Kebangkitan politik identitas islam pada Pilkada DKI Jakarta dibangun melalui pembentukan image sebagai muslim yang mayoritas namun terpinggirkan dan merasa terhina sehingga sesama muslim harus memilih calon pemimpin yang seagama (Sari, 2016).

Pada Pilkada serentak tahun 2018, isu politik identitas terus digunakan oleh calon kandidat untuk mendulang perolehan suara. Untuk menyebut beberapa contoh, Pilkada Jawa Barat memperlihatkan kandidat yang kurang populer diusung oleh Partai Gerindra dan PKS nyaris memenangkan kontestasi elektoral karena kampanye politik yang sangat kental dengan sentimen agama. Sementara pada Pilkada Sumatera Utara, politik identitas juga mendominasi masa-masa kampanye yang berakhir pada kemengan calon kandidat yang didukung oleh PKS dan Gerindra (Simandjuntak, 2018).

Bangkitnya politik identitas dapat dilihat dari dua hal (Romli, 2019): pertama, dalam pemilihan kepala daerah, calon kandidat dan pendukungnya cenderung menggunakan sentimen etinisitas dan agama. Dalam konteks ini, kampanye politik yang sering digemborkan oleh calon kandidat adalah menggiring pemilih untuk memilih calon yang berasal dari wilayah, etnis atau agama yang sama. Kedua, munculnya tuntutan di beberapa daerah unuk menerapkan peratuan daerah berdasarkan agama (perda syariah). Hal ini tidak lepas dari peluang otonomi daerah yang memberikan wewenang kepada kepala daerah untuk membuat peraturan daerah, termasuk regulasi syariah sesuai dengan kebutuhan dan aspirasi masyarakat lokal. Sejak tahun 1998, terhitung tidak kurang dari 443 perda syariah telah diterapkan di Indonesia.

Tidak hanya pada arena politik di tingkat lokal, dalam politik nasional, praktik politik identitas terus mewarnai perjalanan demokasi di Indonesia pasca Orde Baru. Pada masa pemilihan presiden tahun 2014 dan 2019 yang mengkontestasikan calon presiden antara Jokowi dan Prabowo sangat kental dengan nuansa politik identitas. Misalnya hal ini dapat terlihat dalam skema pemilihan calon wakil presiden. Komposisi antara calon presiden dan wakil presiden senantiasa mempertimbangkan dua representasi kekuatan politik yaitu nasionalis dan agama. Terpilihnya Ma'ruf Amin sebagai calon wakil presiden mendampingi Jokowi pada kontestasi pemilihan presiden periode 2019-2024 tidak lepas dari pilihan rasional untuk mendapatkan simpati pemilih muslim khususnya kalangan Nahdliyin (NU), salah satu organisasi muslim terbesar di Indonesia. Terlebih selama ini, figur Jokowi selalu diserang oleh rival politiknya sebagai anti islam dan berpihak pada asing (Perdana \& Wildianti, 2019). Sebagai sebuah negara dengan mayoritas penduduk muslim, pertarungan berebut suara dari pemilih muslim menjadi sebuah pilihan logis dan selalu terjadi dalam setiap perhelatan pesta demokrasi. Kendati dikotomi antara santri-abangan semakin kabur, tetapi strategi politik yang menekankan pada pentingnya pasangan calon yang merepresentasikan santri-abangan atau nasionalis-sekuler dan islam masih sangat kuat (Zuhro, 2019).

Salah satu hal untuk memperkuat bekerjanya politik identitas dalam politik elektoral pada pemilihan presiden dapat dilihat dari masa kampanye. Hasil survei Kompas yang dilakukan menjelang pemilu 2019 menunjukan bahwa sebanyak 24,5\% menyebut bahwa masa kampanye dipenuhi dengan isu politik identitas berbasis agama, suku, ras dan golongan. Sedangkan 
sebanyak 27,1 \% mengungkap bahwa masa kampanye dihiasi dengan isu yang mengasut atau mengadu domba. Data ini mengkonfirmasi bahwa isu-isu identitas dipilih sebagai strategi kampanye oleh kedua pasangan calon. Implikasinya, ruang publik terkait pemilihan presiden disesaki oleh perdebatan soal identitas etnis dan agama yang kerap kali berujung pada tindakan saling serang antar kedua kubu. Implikasinya, pemilu tidak banyak mengahadirkan perdebatan programatik dan agenda pembangunan yang akan dilakukan oleh calon pemimpin. Pemilih menjadi semakin tidak rasional dalam menentukan hak pilihnya karena logika memilih selalu dikontruksi oleh elit dengan membantugun ikatan emosional berdasarkan sentimen identitas. Akibatnya, pertimbangan kualitas dan rekam jejak calon tidak menjadi prioritas utama. Sebab yang lebih utama bagi pemilih adalah pertimbangan soal siapa calon kandidat yang memiliki identitas yang sama dengan karateristik pemilih.

Kampanye politik menggunakan poltik identitas dan sering dikemas dengan berita bohong membuat masyarakat Indonesia terjebak pada pusaran konflik yang bekepanjangan. Kenyataan bahwa masyakat Indonesia memiliki identitas yang beragam dan berpotensi konflik, justru konflik tersebut semakin dipertajam oleh elit politik setiap kali memasuki momentum pemilu dengan membangun sentimen identitas. Implikasinya, disintegrasi di tengah masyarakat semakin sulit dibendung. Dikotomi antara "cebong" dan "kampret" sebagai label yang merepresentasikan dukungan pemilih terhadap dua kubu calon kandidat Jokowi dan Prabowo adalah bukti nyata hadirnya konflik di tengah masyakat.

Politik identitas tidak hanya dapat dipakai untuk menjelaskan dinamika politik elektoral, tetapi juga dapat digunakan untuk menganalisa berbagai kasus kekerasan dan konflik di tengah masarakat di luar isu politik elektoral. Pergeseran sistem otoriter menuju demokrasi ternyata tidak banyak memberi harapan terhadap terwujudnya kehidupan sosial politik yang damai dan tentram di bawah payung nasionalisme. Kasus Papua yang terjadi akhir-akhir ini sukses mencuri perhatian publik. Aksi demonstrasi yang diikuti oleh kekerasan dan pergolakan massa muncul ke permukaan sebagai bentuk ketegangan vertikal dan horizontal. Ketegangan vertikal terjadi antara etnis Papua terhadap pemerintah pusat yang dianggap gagal dalam menghadirkan keadilan dan kesejahteraan sosial-ekonomi di tanah Papua. Desain otonomi khusus untuk Papua yang diikuti dengan sejumlah transfer anggaran ternyata tidak bekerja efektif dalam meredam ketidakpuasaan rakyat Papua terhadap pemerintah.

Sementara ketegangan horizontal terjadi antar kelompok identitas yang berbeda di suatu wilayah. Ketegangan antara warga pribumi dan non-pribumi di Papua masih menjadi narasi yang sangat kuat dalam kehidupan sosial politik. Kerusuhan yang terjadi di Wamena yang menyerang warga pendatang dari etnis non-Papua adalah fakta empiris akan munculnya konflik identitas. Sedikitnya tidak kurang dari 32 orang pendatang di Papua meninggal akibat kerusuhan di Papua. Ketegangan di Papua awalnya dipicu oleh masalah rasisme yang dialami oleh mahasiswa Papua di asrama Malang dan Surabaya. Hal ini menyebabkan kemarahan masyarakat Papua dengan melakukan berbagai demonstrasi dan aksi kekerasan hingga melibatkan warga pendatang di tanah Papua (cnnindonesia.com, 2019).

Tidak hanya konflik etnis, masyarakat Indonesia masih sangat berpotensi terhadap munculnya konflik atas nama agama atau kepercayaan. Tentu kita masih ingat dengan peristiwa pembantaian yang dialami warga Jamaah Ahmadiyah di Cikeusik, Banten pada tahun 2011 silam. Ribuan warga Cikeusik menunutut untuk membubarkan Jamaah Ahmadiyah karena dianggap 
memiliki aliran kepercayaan yang menyimpang. Sedikitnya 3 korban meninggal atas peristiwa berdarah ini (nasional.tempo.co, 2019). Kasus-kasus kekerasan atas dasar agama atau kepercayaan juga banyak terjadi di daerah lain di Indonesia. Berdasarkan hasil laporan dari The Wahid Institute tahun 2014 mengenai kebebasan beragama atau berkeyakinan dan intolerensi mengungkap sepanjang tahun 2014 terdapat 158 peristiwa dengan 187 tindakan pelanggaran kebebasan beragam/berkeyakinan yang melibatkan aktor negara maupun aktor non-negara. Sedangkan jumlah korban pelanggaran dan intoleransi yang dilakukan oleh aktor negara sebanyak 347 jiwa dan sebanyak 89 korban dilakukan oleh aktor non-negara. Bentuk-bentuk pelanggaran dan intoleransi beragama ini meliputi tindakan serangan fisik dan perusakan properti, penyebaran kebencian, penyesatan terhadap kelompok lain, diskriminasi atas dasar agama, pemaksaan keyakinan, pembatasan dan pemaksaan berekspresi (The Wahid Institutue, 2014).

Pemaparan ini mempertegas bahwa gelombang demokratisasi yang diperkanalkan sejak keruntuhan Orde Baru justru diikuti oleh kebangkitan politik identitas yang berujung pada konflik atas dasar identitas baik vertikal maupun horizontal. Fakta masyarakat yang beragam dan tidak menyatu dan cenderung berkonflik sebagaimana tesis Furnival, justru semakin dipertajam oleh elit politik setiap kali menjelang momentum pemilu baik di tingkat lokal maupun nasional. Perbedaan identitas di tengah masyarakat diaktivasi oleh calon kandidat, partai politik dan pendukung untuk memobilisasi pemilih demi suksesi kontestasi elektoral. Akibatnya masyarakat terus berada dalam bayang-bayang disintegrasi bangsa.

\section{Kesimpulan}

Kebangkitan politik identitas di Indonesia pasca pemerintahan Soeharto menyebabkan perjalanan demokrasi di Indonesia selama dua dekade tidak berjalan maju ke arah demokrasi substansial. Demokrasi Indonesia pada akhirnya masih terjebak pada demokrasi prosedural yang hanya berkelindan soal urusan pemilu dan proses pergantian elit. Namun dalam praktik kehidupan warga negara masih belum menunjukkan kehidupan yang demokratis. Berbagai kasus kekerasan dan intoleransi serta menguatnya sentimen identitas atas dasar etinisitas dan agama telah menimbulkan praktik diskriminasi dan pengeksklusian terhadap kelompok identitas lain yang berbeda. Kondisi ini sering kali dimanfaatkan oleh elit politik yang memainkan peran penting dalam mempertajam sentimen identitas dan agama untuk mendapatkan kekuasaan, terutama memasuki masa pemilu. Hal ini membuat demokrasi Indonesia mengalami regresi.

\section{Referensi}

Abdillah, U. (2002). Politik Identitas Etnis : Pergulatan Tanda Tanpa Identitas. Magelang: Indonesia Tera.

Ambardi, K. (2009). Mengungkap Politik Kartel: Studi Tentang Sistem Kepartaian di Indonesia Era Reformasi. Jakarta: Gramedia \& LSI.

Buchari, S., R. (2014). Kebangkitan etnis menuju politik identitas. Jakarta: Yayasan Pustaka Obor Indonesia.

Chandakirana, K. (1989). Geertz dan Masalah Kesukuan. Jakarta. Prisma No. 2/1989.

Cnnindonesia.com. (2019). Polisi Sebut 33 Korban Tewas Di Wamena Akibat Kerusuhan. Online. Diakses dari https://www.cnnindonesia.com/ nasional/2019102820460220443648/polisi-sebut-33-korban-tewas-di-wamena-akibat-kerusuhan 
Fukuyama, F. (2018). Identity: The Demand for Dignity and the Politics of Resentment. New York: Farrar, Straus, and Giroux

Geertz, Clifford. (1963). The Integrative Rovolution: Primordial Sentiments and Civil Politics in The New States. New York: Free Press.

Geertz, Clifford. (1983). Abangan, Santri, Priyayi Dalam Masyarakat Jawa. Jakarta: Dunia Pustaka Jaya.

Hamid, A. (2019) Populism In The 2017 Jakarta Gubernatorial Election. Journal of Governance, Vol 4, No 1

Jumadi. (2003). Fenomena Etnis Dalam Proses Rekruitmen Elit Politik Lokal: Kasus Pemilihan Bupati dan Wakil Bupati Kabupaten Ketapang Kalbar 2000-2005. Yogyakarta. Tesis UGM.

Morowitz. D., L. (1998). Demokrasi Pada Masyarakat Majemuk. Dalam Larry Diamond dan Mars F Plattner. Nasionalisme, Konflik Etnik dan Demokrasi Bandung. ITB Pres

Habbodin, M. (2012). Menguatnya Politik Identitas Di Ranah Lokal. Jurnal Studi Pemerintahan, Vol 3 , No 1.

Haryanto. (2009). Elit Politik Lokal dalam Perubahan Sistem Politik. Jurnal Sosial Politik, Vol 13, No 2.

Huntington, S.,P. (2007). Benturan Antarperadaban dan Masa Depan Politik Dunia (terj.). Yogyakarta: Qalam

Lee, H. (2009). Furnivall's Plural Society and Leach's Political Systems of Highland Burma. Sojourn: Journal of Social Issues in Southeast Asia, 24(1), 32-46. Retrieved from www.jstor.org/stable/41308110

Levistky, S \& Ziblat, D. (2018). Bagaimana Demokasi Mati. Jakarta: Gramedia Pustaka Utama

Mietzner, M. (2008). Comparing Indonesia's party systems of the 1950s and the post-Suharto era: From centrifugal to centripetal inter-party competition. Journal of Southeast Asian Studies, 39(3), pp 431-453 October 2008.

Perdana, A \& Wildianti, D. (2019). Narasi Kampanye dan Media Sosial dalam Pemilu Presiden dan Wakil Presiden Tahun 2019. Jakarta: Bawaslu RI.

Nasional.tempo.co. (2019). Kronologi Penyerangan Jamaah Ahmadiyah Di Cikeusik. Online. Diakses dari https://nasional.tempo.co/read/311441/kronologi-penyerangan-jamaahahmadiyah-di-cikeusik

Nordholt, H, S., \& Klinken, G. (2007). Politik Lokal Di Indonesia. Jakarta: Yayasan Obor Indonesia dan KITLV Jakarta

Robinson, R., \& Hadiz, V. (2004). Reorganizing Power in Indonesia: The Politics of Oligarchy in Age of Markets. London: Routletge.

Romli, L. (2019). Political Identity and Challenges for Democracy Consolidation in Indonesia. Politik Indonesia: Indonesian Political Science Review, Vol 4, No 1.

Santoso, Purwo. (2011). Proliferation of Local Governments in Indonesia: Indentity Politics within a Troubled Nation State. Journal of Power Conflict Democracy, Vol 3, No 1.

Sari, Endang (2016). Kebangkitan Politik Identitas Islam Pada Arena Pemilihan Gubernur Jakarta. Jurnal Ilmu Sosial dan Ilmu Politik, Vol 2, No 2.

Simandjuntak, D. (2018). Identity politics looms over Indonesia's presidential election. Retrieved November 13, 2018, from http://www.eastasiaforum.org/ 2018/1 1/10/identity-politicslooms-overindonesias-presidential-election/ 
Slater, D. (2004). Indonesian Accuntability Traps: Party Cartels and Presidential Power After Democracy Transition. Indonesia, No. 78 (Oktober).

The Wahid Institute. (2014). Laporan Tahunan Kebebasan Beragama/Berkeya-kinan dan Intoleransi. Jakarta: The Wahid Institue.

Tirto.id. (2017). 13 Hari Pembantaian Orang Cina di Jakarta. Online. Diakses dari https:/ / tirto.id/13-hari-pembantaian-orang-cina-di-jakarta-cx2Y

Tornquist, O. (2013). Assessing dynamics of democratisation: Transformative politics, new institutions, and the case of Indonesia. China: Palgrave Macmillan.

Tornquist, O \& Savirani, A. (2016). Reclaiming The State: Mengatasi Problem Demokrasi di Indonesia Pasca-Soeharto. Yogyakarta: PolGov.

Ubaid, A.,H \& Habibusabandi, H.,B. (2017). Political Polarization based on Religious Identities: Empirical Evidence from the 2017 Jakarta Gubernatorial Election. Jurnal Studi Pemerintahan, Vol 8, No 4.

Winters, J. (2014). Oligarchy and Democracy in Indonesia. In M. Ford, \& T. Pepinsky, Beyond Oligarchy: Wealth, Power, and Contemporary Indonesian Politics. New York: Cornell University Press.

Zuhro, R. S. (2019). Demokrasi Dan Pemilu Presiden 2019. Jurnal Penelitian Politik, Vol 16, No 1. 